\title{
Nasserism and the impossibility of innocence
}

\author{
Zeyad el Nabolsy ${ }^{1}$
}

Accepted: 5 February 2021

(c) The Author(s), under exclusive licence to Springer Nature Limited part of Springer Nature 2021

One of the central strengths of Salem's analysis of Nasserism is that she recognizes both its world-historical significance as a progressive nationalist movement, and its severe limitations. In the first section of this paper, I discuss Salem's notion of the "afterlives" of the Nasserist project by drawing attention to one of the most debilitating legacies of that project, namely the transformation of Egyptian politics into petty bourgeois politics. In the second section, I argue that while Salem does not explicitly draw on Hegel's understanding of tragedy in her account of Nasserism, her analysis of Nasserism essentially amounts to depicting it as a Hegelian tragedy. By placing Salem's book in conversation with Hegel (and his philosophy of action), we can make explicit what I take to be one of the central claims made by Salem, namely that when passing judgment on past and present national liberation movements we should remember that innocence is "only non-action, like the mere being of a stone" [nur das Nichttun wie das Sein eines Steines] (Hegel 1986, 346). In the third section of this paper, I raise some critical points about Salem's characterization of the nationalism that was associated with the Nasserist project, as well as about the deployment of the concept of modernity in her analysis. I argue that her account of modernity in the book does not distinguish between the concept of modernity as it refers to a certain kind of normative philosophical discourse, and modernization theory qua theory of development. Finally, I draw on Salem's use of the concept of hegemony in order to pose a question regarding the political significance of the contemporary cultural hegemony of Islamist movements in Egypt.

\section{Nostalgia and the afterlives of petty bourgeois politics}

Salem argues that the Nasserist project was the only truly hegemonic project in Egypt's modern history. Salem convincingly argues that the hegemony of the Nasserist project could not have been built by "repeating empty rhetorical slogans year after year" (Salem, 135). Instead, it appealed to many Egyptians from different social classes because it drew on ideas that were already held by them, such as the

\footnotetext{
Zeyad el Nabolsy

ze44@ cornell.edu

1 Cornell University, Ithaca, USA
}

Published online: 01 March 2021 
importance of national sovereignty, the creation of a social welfare state, and development through industrialization. In other words, workers were not "duped" by the proponents of the Nasserist project, they agreed with some of the aims of that project, and they benefitted materially from the implementation of that project. ${ }^{1}$ The mechanism by means of which Nasserism was able to accomplish this is interesting because it illustrates both the world-historical significance of the national liberation movements which were led by the petite bourgeoisie and their structural limitations. Salem points out that the Nasserist project succeeded because its political tenets were not entirely new (Salem, 132). It drew on ideas and goals that had been elaborated in the decades before 1952 by working-class movements and feminist movements. However, while this project actualized some of the ideas of workingclass movements, it disempowered their independent organizations. The same is also true of Nasserism's relationship with feminist movements, e.g., while attempts were made to allow women to move from the sphere of social reproduction to the (public) "sphere of production", independent organizations such as the Egyptian Feminist Union were shut down. Salem argues that this approach prevented successful challenges to the emergence of Sadat's dependent bourgeoisie (Salem, 260).

I would also add that the most damaging limitation of Nasserism is that it eventually led to the disfiguration of Egyptian politics and to its transformation into middle-class politics(Batatu 1983, 16).By this I mean that Nasserism empowered the petite bourgeoisie to define political discourse and practice in Egypt (a trend which continues today). While it is to true that Nasserism appealed to many classes, its primary constituency was the class of bureaucrats and technocrats who now had a path towards social mobility through educational reforms and through the expansion of the public sector. In other words, if we agree with Salem that Nasserism has overshadowed all subsequent Egyptian history (Salem, 147), then we should also point out that it has constrained Egyptian politics within the framework of petty bourgeois politics (Amin, 1978, 65).

One of the lingering shadows of the "afterlives" of Nasserism is that many of those who attempted to struggle against the Infitah project under Sadat as well as the acceleration of neoliberalization during the 1990s and 2000s have been unable to articulate an alternative vision of Egypt that is not reducible to nostalgia. Vacillation and nostalgia are characteristics of petty bourgeois politics, ${ }^{2}$ and it would not be inaccurate to say that they are the dominant modes of politics in Egypt today. The petite bourgeoisie's vacillation is the outcome of its class position; it is both subjected to pressures from the bourgeoisie and yet it fears any political movement that is led by the working-class. Its nostalgia is the product of the recognition that if current socioeconomic trends continue into the future, the petite-bourgeoisie will

\footnotetext{
1 The invaluable oral history which has been compiled by Abu Al-Leil (2015) also supports Salem's point.

2 As Marx and Engels note, the petite bourgeoisie is always "fluctuating between proletariat and bourgeoisie, ever renewing itself as a supplementary part of bourgeois society" (Marx and Engels 2007, 34).
}

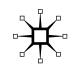


cease to exist as a class (by being pushed down into the working-class). ${ }^{3}$ Hence, this class can imagine itself as having a future only if history can somehow be made to go backwards in time.

Today, we see this nostalgia at work on both the right and the left in Egypt. On the right, we see pro-monarchist propaganda which falsely paints the pre-1952 period as modern Egypt's "golden age". On the left, we see Nasserists uncritically harkening back to the 1950s and 1960s, and blaming individual traitors for the collapse of the Nasserist project. ${ }^{4}$ This moralizing nostalgia, which is incapable of accommodating any kind of structural analysis, is a debilitating feature of contemporary Egyptian political challenges to the neo-liberal restructuring of Egypt. Nostalgia is also essential to the discourse of Islamist groups like the Muslim Brotherhood (in this case nostalgia for a unified and powerful Muslim ummah).It is therefore no exaggeration to say that, in Egypt, the past "weighs like a nightmare on the brains of the living" (Marx 1996, 32).

If examine the social base of the Muslim Brotherhood, we find that, while its leading figures are merchants like Khairat al-Shater who have benefitted from the Infitah(Salem, 185-191), the cadres of the party are primarily from the petite bourgeoisie (Ismail 2020). It is worth pondering why the class which benefitted the most from the Nasserist project was the class that also threw its weight behind the Islamist movements which contributed to the dismantling of that very same project, and then proceeded to dance on its grave. This might be taken as evidence that to build a political project with the petite bourgeoisie as a social base is to build on weak, unstable foundations. It may in fact be the case that the cultural hegemony of Islamism in contemporary Egypt is but a manifestation in the cultural sphere of the dominance of the petite bourgeoisie over the Egyptian political imaginary.

This is not to say that there is no significant difference between petty bourgeois political discourse that is carried out with the aim of breaking with dependency, and petty bourgeois political discourse that is carried out with the aim of fostering dependency. Nasser's political discourse, despite its many limitations, was fundamentally anti-imperialist and directed against dependency, whereas Sadat was unabashedly in favor of subordinating Egypt to US imperialism. Nonetheless, the fact remains that the former was afflicted with structural limitations, which placed it in a position of vulnerability in relation to the latter. Such structural limitations were evident in the aftermath of the 1967 defeat which effectively brought about the end of the Nasserist project. In the aftermath of defeat there were repeated calls for the launching of a "people's war" to liberate the occupied lands, i.e., a war that would both presuppose progressive social changes and help catalyze them, yet such calls

\footnotetext{
${ }^{3}$ This is the real import of the frequent laments that are heard in Egypt today about the "decline of the middle class".

${ }^{4}$ Sadat may have been a traitor, but Sadat is also what you get when you try to build "socialism without socialists".
} 
were ultimately ignored in favor of an attempt to preserve a national independence project that was led by the petite bourgeoisie (Sharawy 2019, 222-224). ${ }^{5}$

Amílcar Cabral argued that the petite bourgeoisie leading the struggle against colonialism could take one of two paths. The first path, the one taken by most petty bourgeois national movements, involves preventing the peasantry and the workingclass from developing autonomous movements and organizations, in which case the petite bourgeoisie would "transform itself into a national pseudo-bourgeoisie, that is to deny the revolution and necessarily subject itself to imperialist capital"(Cabral 1979, 136). The other path, which was taken by few movements, involves allowing the working-class and the peasantry to direct the struggle, which requires that the petite bourgeoisie in power should "commit suicide as a class" (Cabral 1979, 136). ${ }^{6}$ In the aftermath of 1967 , the petty bourgeois officers, technocrats, and bureaucrats were called upon to commit class suicide in the Cabralian sense, and they ultimately failed to do so.

Nonetheless, Cabral's analysis is not without its problems. A key problem with Cabral's call for the petite bourgeoisie leading national liberation struggles to commit class suicide is that it requires that the petite bourgeoisie should, on the one hand, trust itself insofar as it is required to play an indispensable role in the national liberation struggle. On the other hand, it requires that the petite bourgeoisie should develop an awareness of its own weakness, and that it should fundamentally distrust itself. For it must keep in view the fact that without allowing the peasantry and the working class to direct the struggle (which requires that they be allowed to develop autonomous organizations), the petite bourgeoisie is always susceptible to becoming transformed into a "national pseudo-bourgeoisie". From the standpoint of logical analysis, there is no contradiction in what Cabral demands; but from a praxis-oriented standpoint (which must account for empirically given psychological profiles), it is difficult to see how one can simultaneously act on both beliefs in a sustained manner. We may ask: Could the officers involved in the Nasserist project have accomplished what they did (and they did accomplish much), if they did not harbor illusions about the ability of the petite bourgeoisie to arrest its inevitable slide towards surrender and dependency? In other words, Nasserism might have been based on an illusion, but perhaps this illusion was historically necessary.

\section{The Nasserist project as Hegelian tragedy}

Unlike many one-sided discussions of Nasserism, Salem's book is sensitive to both the accomplishments of the Nasserist project and the sacrifices that it demanded. This is brought out in her analysis of the construction of the Aswan High Dam,

\footnotetext{
5 In the aftermath of 1967, there were also calls by the Marxist writers around al-Tali' ' for Egypt to follow the Cuban model (Gervasio 2010, 232).

${ }^{6}$ Cuba is an example of this second path. Maybe Nasserists would do well to study Cuba, since undoubtedly there were "Sadats" in Cuba (for surely, they exist everywhere), but unlike in Egypt, they have never been able to obtain state power.
} 
which was seen as a necessary step for Egypt's modernization, but whose construction led to the displacement of Nubians in Upper Egypt and Wadi Halfa in Northern Sudan as well as to the death of some of the workers involved in the project (Salem, 270-271). ${ }^{7}$ The need to erect the dam in order to provide electricity to power the import-substitution industrialization program clashed with the demands of Nubians to not be displaced from their ancestral lands. Salem's sensitivity to both the violence that accompanied the Nasserist national liberation project and to the historical significance of that project as an attempt to break with dependency is a key strand in the book. Salem is critical of the Nasserist project, but her critique takes into account the historical constraints within which that project unfolded. Hence, it is not a critique from the romantic standpoint of what Hegel calls "the beautiful soul" (which is analyzed below).

I argue that while Salem does not explicitly draw on Hegel's understanding of tragedy in her account of Nasserism, her analysis of Nasserism essentially amounts to depicting it as a Hegelian tragedy. As Mark W. Roche notes, "For Hegel tragedy is the conflict of two substantive positions, each of which is justified, yet each of which is wrong to the extent that it fails either to recognize the validity of the other position or to grant it its moment of truth" (Roche 2006, 12). In other words, what was tragic about the Nasserist project is that many of its internal conflicts pitted right against right. $^{8}$ It seems to me that this reading accords with Salem's insistence that the failures of the Nasserist project (and other equivalent anticolonial projects) cannot be solely blamed on inadequate decision-making processes (Salem, 278). However, this is not to say that guilt is absent here. What is especially interesting about employing a Hegelian conception of tragedy to analyze the Nasserist project is that it brings to the fore the question of whether anti-colonial projects had to be "one-sided" in order to be efficacious. According to at least one reading of Hegel, all efficacious action in the world is of necessity one-sided-those who engage in it can only do so by marginalizing principles that have an equally valid normative claim upon them (Oudemans and Lardinois 1987, 114-115). If this framing is appropriate, then we can say that the proponents of the Nasserist project were guilty and that their guilt was an unavoidable consequence of their (efficacious) struggle against a colonial and neo-colonial international order.

Of course, even if Hegel is right and all action involves guilt, it still does not follow that all actors are guilty to the same degree. It only implies that when passing judgment on past and present national liberation movements we should remember that innocence is "only non-action, like the mere being of a stone" [nur das Nichttun wie das Sein eines Steines] (Hegel 1986, 346). To demand that a group of people should undertake any action of world-historical significance while remaining entirely innocent is to demand the impossible.

\footnotetext{
7 We also should not forget that under the monarchy Egyptian Nubia was even more neglected by the central government than it is today. For example, in the decades before 1952, there was only one primary school in all of Egyptian Nubia (Abu Al-Leil 2015, 160).

${ }^{8}$ I emphasize "internal conflicts" because I think that it is obvious that Nasserism's external conflicts with colonialism and neo-colonialism did not instantiate a struggle of "right against right". No right can be found on the colonial/neo-colonial side.
} 
The significance of this point is that it allows us to differentiate between two kinds of critiques of the Nasserist project (and of the Bandung-era national liberation movements in general). One kind of critique proceeds by pointing to the possibilities that were foreclosed by the Nasserist project, while also recognizing that at least some of the internal struggles that it engendered were tragic in the Hegelian sense insofar as they pitted right against right. I regard this type of critique as legitimate and necessary. The second kind of critique proceeds from the detached standpoint of what Hegel calls "the beautiful soul" [die schöne Seele] (Hegel, 1986, 464). The beautiful soul understands that to engage in any action is to risk sullying one's hands, and that maintaining moral purity is incompatible with being an active agent in the world. The beautiful soul values moral purity above all else, and hence it refuses to act. Yet it does not refrain from passing judgment on those who act: "the beautiful soul is the self-righteous critic who is proud of never actually doing anything" (Magee 2010, 44). This second type of critique applied to the Nasserist project (and other Bandung-era movements) is harmful because it gives rise to unreasonable expectations regarding what a "legitimate" nationalist emancipatory movement should look like. ${ }^{9}$ It essentially amounts to a rejection of any efficacious action towards emancipation, since any efficacious action will involve a degree of guilt. If I have understood Salem correctly, we are essentially in agreement that the standpoint of the "beautiful soul" is not an adequate standpoint from which to criticize Nasserism.

\section{Was the Nasserist project too modernist or not modernist enough?}

I now wish to raise three questions in relation to Salem's book. The first question has to do with how we should understand the differences, if there are any, between the nationalism espoused by the proponents of anti-colonial projects such as the Nasserist project and the European nationalisms of the nineteenth and twentieth century? Salem argues that one of the pitfalls of the Nasserist project is that its leaders did not understand that adopting nationalism for more than merely strategic considerations was problematic (Salem, 149). The implication here is that at a fundamental level "Third World" nationalisms were not really different in kind from the nationalisms of colonial countries. However, it is not clear to me that this is true. As I have argued elsewhere, there were attempts to rethink nationalism in the post-colonial context such as to differentiate it from nationalism as it developed in its nineteenth-century European form (El Nabolsy 2020a). Salem does indeed draw on Getachew (2019) in order to argue that anticolonial nationalisms were characterized by internationalist attempts to remake the world (Salem, 79). However, it is unclear, if, on her

\footnotetext{
9 Hegel's analysis of the beautiful soul can serve as an analysis of "ultra-leftism" and its consequences. Readers can decide for themselves whether, for example, much of the contemporary discourse on the left around Bolivia's "exctractivism", under the rule of the Movement for Socialism party, is the product of "beautiful souls" in the aforementioned sense.
} 
account, anticolonial nationalism has any progressive role to play in the world today. For what it is worth, I am inclined to think that it does.

The second question has to do with the relationship between the concept of modernity and the concept of "coloniality"/colonialism: is modernist discourse essentially colonialist in nature? In some parts of the book it seems that the relationship between the two concepts is not explicitly clarified (Salem, 151-155). My inclination is to make a distinction between modernization theory as a discourse of development, the philosophical discourse of modernity, and colonialism (and its normative justifications). We can point to Cabral as an example of an anti-colonial revolutionary who both embraced the philosophical discourse of modernity, while also rejecting modernization theory and colonialism-along with its attendant normative justifications (El Nabolsy 2020b). It seems that when Salem criticizes the modernism of the Nasserist project, what she really wants to do is to criticize Nasserism's embrace of some aspects of modernization theory. For example, the extent to which modernization theory encouraged industrial development in urban centers by means of the exploitation of the countryside. ${ }^{10}$

Clarification of the relationship between "coloniality" and modernity would also refine Salem's critique of the discourse of "mastery" (Salem, 155). For a fundamental commitment of the philosophical discourse of modernity is a commitment to autonomy (i.e., that humans cannot be bound by any principles that they do not recognize as good-this can also be spelled out in terms of self-legislation). ${ }^{11}$ The relationship between autonomy and mastery needs to be further clarified. Perhaps it is true that self-legislation involves a demand for self-mastery, but is this demand for self-mastery not different from, for example, the discourse of mastery as applied to nature? It seems that we can consistently uphold a demand for self-mastery (as required by self-legislation) while rejecting ecologically damaging discourse about the mastery of nature. In fact, it may be that the rejection of the latter requires the embrace of the former. If this is true, then some kind of discourse invoking mastery is desirable.

Drawing attention to the centrality of autonomy in the philosophical discourse of modernity also allows us to clarify the nature of Salem's critique of the Nasserist project. If it is indeed true, and Salem seems to suggest as much, that a central failing of the Nasserist project is that it undermined the autonomy of individual workers, women, peasants, etc., through undermining the development of independent organizations that allowed for the protection and expression of their individual

\footnotetext{
10 The Nasserist government's policy of holding down food prices meant that the relative prosperity of the workers in the large urban centers was coming at the expense of the peasantry (Mansfield, 1969, 175). However, the Nasserist government seems to have been aware of this, and by 1964 there was an attempt to remove all price controls on locally produced food items.

11 This is the kind of freedom that (along with the personal freedom to choose our own ends) Hegel took to be distinctive of modernity: "the right to recognize nothing that I do not perceive as rational is the highest right of the subject" (Hegel 1991, 159). To use the language of "self-legislation" to describe Hegel's position might be taken to imply that I neglect the differences between Kant and Hegel. However, it seems clear to me that Hegel does not abandon the modernist Kantian concept of self-legislation, but rather he historicizes it. For an overview of interpretive debates regarding this issue, see Stern (2017).
} 
autonomy, ${ }^{12}$ then Salem's critique of the Nasserist project is essentially a critique that draws on the philosophical discourse of modernity. Hence, despite appearances, and perhaps despite her own intentions, Salem is criticizing the Nasserist project for not being modernist enough. Attaining clarity on this point is a desideratum for any clear analysis of the Nasserist project. I believe that this point can be generalized for the analysis of other Bandung-era projects as well. To criticize Bandung-era projects for undermining autonomy means that we are criticizing them on modernist grounds. Therefore, we cannot consistently criticize, on modernist grounds, the Bandung-era projects for undermining individual autonomy while also criticizing them for being "too modernist". In my view, one of the key failings of the Bandungera projects is that they conflated the actualization of the normative principles of modernity with modernization theory qua theory of development. It would be unfortunate for critics of the Bandung-era projects to reproduce this same error.

The final question I wish to raise is related to Salem's use of the concept of hegemony. One of Salem's key theses is that after the collapse of the Nasserist project, no other hegemonic project emerged in Egypt, and hence successive regimes have had to increasingly rely on coercion without being able to create adequate levels of consent. However, Salem is aware that one objection that can be raised against this claim is that since the 1970s and 1980s the Muslim Brotherhood (and Islamist discourse more generally) has managed to become hegemonic. Salem concedes that "there is little doubt that specific elements of Brotherhood influence did become hegemonic, at least culturally" (Salem, 189). Nonetheless, Salem argues, this cultural hegemony has not been translated into a hegemonic political project. Salem explains this by pointing to, among other factors, the fact that the Brotherhood has no alternative economic program. They supported Sadat's Infitah and they supported the accelerated neoliberal reforms during the 1990s and 2000s (Salem, 191). One question that this analysis raises is the extent to which the "Islamization" of the cultural sphere has essentially led to a situation whereby the Muslim Brotherhood's influence is too weak to create an alternative hegemonic project while at the same time remaining too strong to allow for the emergence of a secular, emancipatory hegemonic project in Egypt? It seems that without reversing the cultural dominance of the Muslim Brotherhood and other Islamist groups, Egypt will continue to exist in what Salem calls "empty time" - a temporal period characterized by the absence of any attempt to build a coherent political project that can aspire to become hegemonic. We may connect this point to our discussion of the question of modernity. In the Egyptian context, it is unclear if a political project that turns its back on modernity (for instance, by equating it with colonialism/coloniality), can offer any kind of resistance to the cultural hegemony of Islamist movements. Hence, clarifying what modernity means and what a modernist political project should and can look like remains a pressing intellectual task.

\footnotetext{
12 The concept of collective autonomy can be derived from the concept of individual autonomy. Rousseau is often identified as a key thinker in the development of the concept of collective autonomy and its analogues (Todorov 2009). A point that is also made by C. L. R. James who makes the bold claim that "after Karl Marx, Rousseau is the most important figure in modern history" (James 2009, 105).
} 
Acknowledgements I am grateful for Alina Sajed's tremendously helpful comments on an earlier draft of this paper.

\section{References}

Abu Al-Leil, K. (2015). Al-tārikh al-sh'ab̄̄ le-mișr fi fatrat al-hukum al-Nasserī[The Popular History of Egypt during the Nasserist Period]. Egyptian General Book Organization.

Amin, S. (1978). The Arab Nation: Nationalism and class struggle. Translated by Michael Pallis. Zed Press.

Batatu, H. (1983). The Egyptian, Syrian, and Iraqi revolutions: Some observations on their underlying causes and social character. Center for Contemporary Arab Studies, Georgetown University.

Cabral, A. (1979). The weapon of theory. Unity and struggle: Speeches and writings of Amílcar, translated by Michael Wolfers (pp. 119-137). Monthly Review Press.

El Nabolsy, Z. (2020a). Lotus and the self-representation of Afro-Asian writers as the vanguard of modernity. Interventions International Journal of Postcolonial Studies. https://doi.org/10.1080/13698 01X.2020.1784021

El Nabolsy, Z. (2020b). Amílcar Cabral's modernist philosophy of culture and cultural liberation. Journal of African Cultural Studies, 32(2), 231-250.

Gervasio, G. (2010). Al Haraka al Marxiya fe Misr (1967-1981) [The Marxist Movement in Egypt (1967-1981)]. Translated by Basma Mohammed Abdelrahman and Carmini Cartolano. National Center for Translation.

Getachew, A. (2019). Worldmaking after Empire: The rise and fall of self-determination. Princeton University Press.

Hegel, G. W. F. (1986). Phänomenologie des Geistes. Werke in zwanzig Bänden, Band 3. Edited by Eva Moldenhauer and Karl Markus Michael. Suhrkamp Verlag.

Hegel, G. W. F. (1991). Elements of the philosophy of right. Translated by H. B. Nisbet. Edited by Allen W. Wood. Cambridge University Press.

Ismail, S. (2020). Kayf aṣbḥt al-bourgeoisīya al-șaghīra hadna l-jamāat al-Ikhwān al-Muslimūn [How the Petite Bourgeoisie Became an Incubator for the Muslim Brotherhood]. Hafryat January 16, viewed October 13, 2020. Retrieved from https://www.hafryat.com/ar/blog/\%D9\%83\%D9\%8A\%D9\%81\%D8\%A3\%D8\%B5\%D8\%A8\%D8\%AD\%D8\%AA-\%D8\%A7\%D9\%84\%D8\%A8\%D8\%B1\%D8\%A C\%D9\%88\%D8\%A7\%D8\%B2\%D9\%8A\%D8\%A9-\%D8\%A7\%D9\%84\%D8\%B5\%D8\%BA\%D9\%8A\%D8\%B1\%D8\%A9-\%D8\%AD\%D8\%A7\%D8\%B6\%D9\%86\%D8\%A9-\%D9\%84\%D8\%AC\%D9\%8 5\%D8\%A7\%D8\%B9\%D8\%A9-\%D8\%A7\%D9\%84\%D8\%A5\%D8\%AE\%D9\%88\%D8\%A7\%D9\%86 $\% \mathrm{D} 8 \% 9 \mathrm{~F}$

James, C. L. R. (2009). Rousseau and the idea of the general will. In D. Austin (Ed.), You don't play with revolution: The Montreal lectures of C.L.R. James (pp. 105-120). AK Press.

Magee, G. A. (2010). The Hegel dictionary. Continuum.

Mansfield, P. (1969). Nasser's Egypt. Penguin.

Marx, K. (1996). The Eighteenth Brumaire of Louis Bonaparte. In T. Carver (Ed.), Marx: Later political writings (pp. 31-127). Cambridge University Press.

Marx, K., \& Engels, F. (2007). The Communist Manifesto. International Publishers.

Oudemans, Th. C. W., \& Lardinois, A. P. M. H. (1987). Tragic ambiguity: Anthropology, philosophy and Sophocles' Antigone. Brill.

Roche, M. W. (2006). Introduction to Hegel's theory of tragedy. PhaenEx, 1.2, 11-20.

Sharawy, H. (2019). Sìra mișriya Ifriqiya [An Egyptian African Story]. Edited by Reem Abou-El-Fadl. Al-Ain Publishing.

Stern, R. (2017). Freedom, norms, and nature in Hegel: Self-legislation or self-realization? In R. Zuckert \& J. Kreines (Eds.), Hegel on philosophy in history (pp. 88-105). Cambridge University Press.

Todorov, T. (2009). Imperfect garden: The legacy of humanism. Translated by Carol Cosman. Princeton University Press.

Publisher's Note Springer Nature remains neutral with regard to jurisdictional claims in published maps and institutional affiliations. 